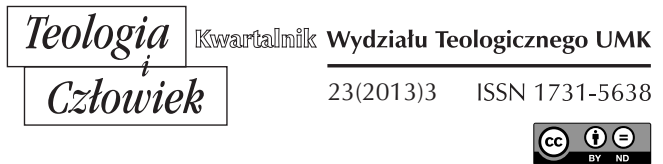

JACEK SALIJ OP*

WARSZAWA

\title{
WIARA JAKO POCZĄTEK ŻYCIA WIECZNEGO
}

DOI: http://dx.doi.org/10.12775/TiCz.2013.032

\section{WIARA JEST CZYMŚ WIĘCEJ NIŻ ŚWIATOPOGLĄDEM}

Zacznę od dwóch tez negatywnych. Począwszy od epoki oświecenia, istnieje $\mathrm{w}$ naszej kulturze tendencja do utożsamiania wiary $\mathrm{z}$ religijnym światopoglądem. Ponadto często można się spotkać z tezą jakoby wiara polegała na posiadaniu religijnych przekonań.

Otóż jeżeli przyjąć, że światopogląd jest to subiektywna odpowiedź na pytania o ostateczny sens świata i człowieka, wiara zazwyczaj zawiera w sobie wymiar światopoglądu, jest ona jednak czymś więcej. Przypomnę dwie sławne historie, kiedy ktoś posiadający zdecydowanie katolicki światopogląd był jednak człowiekiem niewierzącym.

Pierwszym z tych ludzi był sam św. Augustyn, który w pewnym momencie swoich poszukiwań osiągnął pewność co do tego, że

* O. prof. dr hab. Jacek Salij OP - profesor zwyczajny w Katedrze Teologii Dogmatycznej Wydziału Teologicznego Uniwersytetu Kardynała Stefana Wyszyńskiego w Warszawie; konsultor Sekcji Nauk Teologicznych w Komisji Nauki Wiary Episkopatu Polski; wykładowca teologii dogmatycznej na UKSW oraz w Kolegium Filozoficzno-Teologicznym oo. Dominikanów w Krakowie; członek Komitetu Nauk Teologicznych PAN oraz polskiego oddziału PEN Club. 
prawda znajduje się w Kościele katolickim, a zarazem wiedział, że on wciąż jeszcze jest człowiekiem niewierzącym. Swoją ówczesną sytuację duchową opisał w ósmej księdze Wyznań. Momentem przełomowym okazała się słynna scena Tolle, lege. Usłyszawszy głos jakiegoś dziecka: „Bierz i czytaj”, Augustyn otworzył List do Rzymian i natrafił na słowa: „nie w hulankach i pijatykach, nie w rozpuście i wyuzdaniu, nie w kłótni i zazdrości, ale przyobleczcie się w Pana Jezusa Chrystusa i nie troszczcie się zbytnio o ciało, dogadzając żądzom" (Rz 13,13-14). Właśnie wtedy Augustyn uwierzył1 ${ }^{1}$. Dotychczas bał się otworzyć na łaskę wiary, bo wiedział, że jest człowiekiem zbyt słabym, żeby zachować rzetelnie Boże przykazania. $\mathrm{W}$ tamtym momencie zrozumiał, że przecież sam Chrystus Pan będzie go swoją łaską wspomagał. I właśnie w tamtym momencie Augustyn stał się człowiekiem wierzącym, a całe jego życie jest najlepszym świadectwem, jak głęboka i jak całoosobowa była jego wiara.

Na drugiego świadka, że wiara to jest coś więcej niż światopogląd, przywołam jednego z największych teologów katolickich XX wieku, Romano Guardiniego. Kiedy był licealistą, z przerażeniem zorientował się, że - mimo swoich ogromnych zainteresowań religijnych oraz emocjonalnego przywiązania do Kościoła katolickiego - jest chyba człowiekiem niewierzącym, bo z jego modlitwą jest coś nie tak ${ }^{2}$. Wtedy zaczęło się jego wielkie nawrócenie. Zatem nie jest to przypadek, że właśnie Guardini jest autorem tezy, że od strony duchowej ludzie dzielą się nie tyle na wierzących i niewierzących, ile na modlących się i niemodlących. Mówiąc krótko, ważnym przejawem (choć nie istotą) wiary jest szukanie i takie lub inne znajdowanie Boga żywego.

\section{WIARY NIE DA SIĘ RÓWNIEŻ SPROWADZIĆ DO RELIGIJNYCH PRZEKONAŃ}

Drugie mylne wyobrażenie o wierze, jakie mentalność oświeceniowa chciałaby narzucić ludziom wierzącym, to utożsamianie wiary $\mathrm{z}$ religijnymi przekonaniami. Polega to na tym, że nam, wierzącym chrześcijanom, zakazuje się - wprost, choć częściej pośrednio - przesłanie wiary traktować $\mathrm{w}$ kategoriach prawdy obiektywnej. Kiedy na przykład

${ }^{1}$ Por. Augustyn, Wyznania, 8,16; tłum. Z. Kubiak, Warszawa 1982, s. 149-150.

2 Por. Wypowiedź kard. Mariana Jaworskiego, „Więź” 2008, nr 4-5, s.165. 
powiem, że Chrystus jest Zbawicielem wszystkich ludzi, mogę zostać upomniany: „Nie mów tak, możesz co najwyżej powiedzieć, że w twoim przekonaniu albo według wiary twojego Kościoła Chrystus jest Zbawicielem wszystkich ludzi".

Podobnie jeśli powiem, że Chrystus zmartwychwstał, muszę się liczyć z tym, że spotkam się z zarzutem, iż uprawiam duchowy imperializm. Bo zgodnie z mentalnością oświeceniową wolno mi co najwyżej powiedzieć, że moim zdaniem Chrystus zmartwychwstał i że jestem co do tego głęboko przekonany.

Ludzie, którzy w ten sposób nas korygują, zapewne nie są świadomi tego, iż w gruncie rzeczy żądają od nas, żebyśmy wyparli się naszej wiary. Przecież być chrześcijaninem znaczy wierzyć, że naprawdę Syn Boży stał się człowiekiem, naprawdę umarł za nas na krzyżu i naprawdę zmartwychwstał. Dość przypomnieć stanowcze twierdzenie apostoła Pawła, że ,jeśli Chrystus nie zmartwychwstał, daremne jest nasze nauczanie, próżna jest także wasza wiara", i że gdyby Chrystus faktycznie nie zmartwychwstał, to my głosząc Jego zmartwychwstanie, ciężko obrażalibyśmy w ten sposób Pana Boga, gdyż „przeciwko Bogu świadczyliśmy, że z martwych wskrzesił Chrystusa" (1 Kor 15,14-15).

\section{TRZY RODZAJE AKTÓW WIARY}

Czym wobec tego jest wiara? Określmy wstępnie, że jest to zdolność do realnych kontaktów z Bogiem i Chrystusem. My, Polacy, kiedy mówimy o wierze, mówimy przede wszystkim, a może nawet wyłącznie o aktach wiary. Sam język nas do tego skłania. Język łaciński - a to jest w końcu źródłowy język zachodniego chrześcijaństwa - używa tu dwóch zupełnie różnych wyrazów: wiara to po łacinie fides, wierzyć zaś to jest credere. W języku polskim obie te rzeczywistości określa się wyrazami mającymi wspólny źródłosłów, toteż praktycznie często ich w ogóle nie rozróżniamy.

Tendencja do utożsamiania wiary z jej aktami - na co zwrócił uwagę papież Benedykt XVI w encyklice Spe salvi i jeszcze o tym będziemy mówić - charakteryzuje zresztą religijne myślenie chrześcijan zachodnich co najmniej od czasów Marcina Lutra. Otóż żebyśmy mogli wyraźniej tę różnicę zobaczyć, przypomnę najpierw, o czym mówimy, kiedy myślimy o aktach wiary. Spróbuję teraz iść śladami św. Tomasza z Akwinu. 
Tomasz rozróżnia trzy rodzaje aktów wiary: „wierzę, że”, następnie „wierzę Bogu” i wreszcie „wierzę w Boga”3. „Wierzę, że” dotyczy materii wiary. Mianowicie za pomocą tych aktów odnosimy się do Boga Żywego, który się nam odsłonił w Jezusie Chrystusie, toteż mieści się $\mathrm{w}$ niej nie tylko prawda o trójjedyności Boga oraz prawda Wcielenia i Odkupienia, lecz także wszystkie dogmaty wiary dotyczące Kościoła, sakramentów oraz naszego przeznaczenia ostatecznego. Dogmaty te bowiem dotyczą nadnaturalnych darów Bożych, których celem jest doprowadzenie nas do wiecznego zjednoczenia z Bogiem. Dlatego wiary nawet w tym pierwszym aspekcie nie da się zastąpić wiedzą, gdyż na drodze rozumu naturalnego można osiągnąć co najwyżej wiedzę o istnieniu Boga i ogólne pojęcie na temat Jego przymiotów.

Do materialnego aspektu wiary św. Tomasz przywiązuje ogromną wagę. Jeśli bowiem Bóg naprawdę udzielił się ludziom w Jezusie Chrystusie, to z pewnością potrafi zapewnić nam nieomylny dostęp do prawdy o tym najważniejszym dziele swojej miłości. Tym bardziej więc znamienne jest twierdzenie Tomasza, że gdyby wiara jakiegoś człowieka ograniczała się do samej tylko pełnej aprobaty umysłu dla wszystkich nauczanych przez Kościół prawd wiary, to o człowieku takim nie można jeszcze powiedzieć, że w ogóle jest człowiekiem wierzącym ${ }^{4}$. Człowiek taki wyznaje jedynie katolicki światopogląd, ale nie ma $\mathrm{w}$ nim jeszcze istotnego dla wiary nadprzyrodzonej osobowego zwrócenia się ku Bogu Żywemu.

Wiara nadprzyrodzona zaczyna się realizować dopiero na poziomie drugim, na poziomie aktów „wierzę Bogu”. U jej początku znajduje się wezwanie Boga, który pierwszy nas umiłował i pragnie coraz więcej oddawać się człowiekowi, aż do niewyobrażalnego zjednoczenia w życiu wiecznym. Ponieważ jest to wezwanie samego Boga, zarazem uzdalnia ono nas do tego, abyśmy mogli na nie odpowiedzieć. Mówiąc inaczej, ta wiara jest owocem łaski Bożej, która pobudza nas do poszukiwań Boga oraz je przenika. Bóg jest bowiem zarówno Kimś Absolutnie Nieskończonym, jak Kimś Osobowym, toteż nawiązanie przez nas osobowego kontaktu z Nim możliwe jest wyłącznie dzięki Jego inicjatywie, którą podejmuje On przez dar łaski.

${ }^{3}$ Summa Theologiae, 2-2, q. 2, a. 2.

${ }^{4}$ Najwyraźniej mówi o tym Akwinata w Wykładzie Listu do Rzymian, cap. 4 lect. 1. 
Do tego, żeby wierzyć Bogu, łaska jest potrzebna z powodu jeszcze dodatkowego. Mianowicie wskutek grzechu pojawiła się w nas ciemna i wobec Boga niesprawiedliwa nieufność do Niego. Toteż skłonni jesteśmy dar prawdy objawionej i łaski, w którym Bóg już teraz daje nam samego siebie, przycinać na miarę naszych ludzkich wyobrażeń i upodobań. Trudno nam wierzyć Bogu, że Jego przykazania są bez reszty słuszne, że są słowem Jego miłości i że bronią naszego dobra. Gotowiśmy też podejrzewać Boga o to, że w sytuacjach różnych nieszczęść i utrapień zostawia nas samym sobie. Dopiero światło łaski może rozświetlić ciemności, w których rodzą się wszystkie te niesprawiedliwe podejrzenia, i skłonić nas do autentycznego uwierzenia Bogu.

Sam jednak akt wiary Bogu - powiada św. Tomasz - nie przybliża nas jeszcze do życia wiecznego, mimo że jest on dziełem łaski i polega na osobowym zwróceniu się ku Bogu Żywemu. Aktem wiary doskonałej, sprawiającej $\mathrm{w}$ nas to poznanie Boga, jakie zostanie uwieńczone wiekuistym oglądaniem Go twarzą w twarz, jest dopiero wierzyć w Boga. To znaczy wierzyć w taki sposób, że Boga stawiamy w naszym życiu i postępowaniu naprawdę na pierwszym miejscu. Dopiero wówczas bowiem wiara staje się utrwaloną postawą, czyli cnotą i jest zmierzaniem do całoosobowego oddania się Bogu.

Termin „wierzyć w Boga” trzeba zwłaszcza nam, Polakom, dobrze wyjaśnić, bo zazwyczaj rozumiemy go jako odpowiednik credere Deum, czyli w sensie: uznaję, że Bóg istnieje. Otóż credere in Deum znaczy nieporównanie więcej. Znaczy mianowicie, że siebie samego i siebie całego staram się zawierzyć Bogu. Zdaniem Akwinaty do takich aktów możemy być tylko zdolni, będąc w stanie łaski uświęcającej. Mówiąc inaczej: żeby wierzyć w Boga, żeby samego siebie Bogu zawierzać, nasza wiara musi być przepojona nadprzyrodzoną miłością Boga. Używając terminologii Tomasza z Akwinu, do takich aktów wiary uzdalnia dopiero fides caritate formata.

To credere in Deum osobiście lubię obrazować odniesieniem do małżeństwa. Mianowicie nie sposób się rzetelnie ożenić, nie sposób na serio wyjść za mąż, jeśli chłopak nie wierzy w swoją dziewczynę, a dziewczyna nie wierzy $\mathrm{w}$ swojego chłopaka; małżeństwo będzie nieudane, jeżeli małżonkowie nie będą wzajemnie wierzyć w siebie, jeżeli zabraknie im postawy: ja tobie zawierzam samego siebie, samą siebie, na dolę i niedolę. Coś podobnego wyrażamy aktem credo in Deum - wierzę w Boga, to znaczy całkowicie zawierzam siebie Panu Bogu. 


\section{DAR, DZIĘKI KTÓREMU JESTEŚMY ZDOLNI DO AKTÓW WIARY}

Przedstawiłem trzy rodzaje aktów credere. Zapytajmy teraz, czym jest fides, wiara, z której te akty wypływają. Najprościej można to pokazać na przykładzie chrztu niemowlęcia. Niemowlę jest jeszcze niezdolne do aktów wiary, a przecież w sakramencie chrztu łaskę wiary już otrzymuje. W encyklice Spe salvi, 10, Benedykt XVI przypomniał, jak się rozpoczynał obrzęd chrztu dziecka w liturgii przedsoborowej: „Kapłan pytał najpierw, jakie imię rodzice wybrali dla dziecka, i kontynuował: O co prosisz Kościół Boży?”. Rodzice wówczas odpowiadali: „O wiarę”. Mówiąc krótko, podobnie jak niemowlę jest już obdarzone rozumem, chociaż jeszcze nie umie go używać, tak samo może otrzymać wiarę, mimo że do aktów wiary jest jeszcze niezdolne. Chrześcijańscy rodzice i bliscy tego niemowlęcia będą je wychowywali w atmosferze wiary, w której nauczy się ono żyć wiarą, stanie się zdolne do aktów wiary.

Wróćmy do dialogu, otwierającego dawną liturgię chrztu dziecka. Kiedy rodzice poprosili o wiarę dla swojego dziecka, chrzciciel stawiał pytanie następne: „Co ci daje wiara?" Rodzice odpowiadali: „Życie wieczne”. Dialog ten Benedykt XVI komentuje następująco: „W tym dialogu rodzice prosili dla dziecka o dostęp do wiary, wspólnotę z wierzącymi, gdyż w wierze upatrywali klucza do «życia wiecznego». Z tym bowiem, tak wczoraj, jak i dziś, mamy do czynienia w Chrzcie, poprzez który stajemy się chrześcijanami: nie tylko z włączeniem do wspólnoty, nie zwyczajnie z przyjęciem do Kościoła. Rodzice oczekują czegoś więcej dla dziecka przyjmującego Chrzest: oczekują, że wiara, do której przynależą materialność Kościoła i jego sakramentów, da mu życie - życie wieczne" (Spe salvi, 10).

Dopiero w świetle tego rozróżnienia wiary i aktów wiary można należycie docenić zaproponowaną przez św. Tomasza z Akwinu definicję: że „wiara jest to sprawność duchowa, mocą której zaczyna się w nas życie wieczne, a która czyni nasz umysł przylegającym do tego, co nieoczywiste". O tym, że wiara jest zalążkiem życia wiecznego w człowieku, czytamy na początku jedenastego rozdziału Listu do Hebrajczyków - i powiem o tym parę zdań za chwilę. Teraz zwrócę uwagę na to, jak łatwo ześlizgujemy się $\mathrm{w}$ fałszywe rozumienie sformułowanej przez Tomasza idei przylegania umysłu do tego, co nieoczywiste. Otóż Tomasz nie twierdzi tu - a tak najczęściej sądzą jego współcześni zarówno admiratorzy, jak i adwersarze - jakoby wiara uzdalniała nasz umysł do przyjęcia nieoczywistych dla niego zdań, w których zawierają się prawdy 
wiary. Wiara kieruje nas przecież ku samemu Bogu, a tylko pośrednio ku zdaniom, dzięki którym jakąś prawdę o Nim poznajemy. Actus credentis non terminatur ad enuntiabile, sed ad rem (Kresem aktu wiary nie jest zdanie ją wyrażające, ale sama rzeczywistość, o której w tym zdaniu się mówi) - mówił Tomasz bez cienia wahania (2-2, q. 1, a. 2 ad 2).

\section{PRAWDZIWY SENS WERSETU HBR 11,1}

Akwinata był teologiem, który starannie unikał popisywania się własną oryginalnością, toteż $\mathrm{w}$ podanej przed chwilą jego definicji wiary bez trudu można zauważyć, że jest ona modyfikacją sformułowań z Hbr 11,1, gdzie wiara została przedstawiona jako sperandarum substantia rerum, argumentum non apparentium. $\mathrm{O}$ właściwe rozumienie tego wersetu, którego sens został kompletnie przeinaczony w Biblii Lutra, sprowadzając wiarę do głębokich przekonań, upomniał się ostatnio papież Benedykt XVI, mianowicie w numerach 7-9 encykliki Spe salvi. Wykład Benedykta XVI na ten temat jest nie tylko ogromnie ciekawy i kompetentny, lecz także cechuje go ponadto duch autentycznego ekumenizmu.

Kluczowym terminem $\mathrm{w}$ tekście oryginalnym tego wersetu jest wyraz hypostasis. „Dla [zachodnich] Ojców Kościoła i teologów średniowiecza było jasne, że greckie słowo hypostasis należało tłumaczyć na łacinę jako substantia" (Spe salvi, 7) - kalką obu tych terminów, i greckiego i łacińskiego, jest polski wyraz podstawa. Również élenchos (po polsku „dowód”), drugi co do ważności termin wyznaczający sens tego wersetu, ma sens nie subiektywny, ale obiektywny, wskazuje na jakąś obecną w nas rzeczywistość. Tymczasem w Biblii Lutra oba te terminy oddano w sensie subiektywnym. Hypostasis Luter oddał jako eine gewisse Zuversicht (swojego rodzaju ufność, przekonanie), élenchos jako das Nichtzweifeln (niepowątpiewanie). Całe zdanie ma w Biblii Lutra sens mniej więcej następujący: wiara jest swojego rodzaju przekonaniem o tym, co do czego ma się nadzieję, oraz niepowątpiewaniem o tym, czego się nie widzi ${ }^{5}$.

Ksiądz Wujek (1599) zdanie to oddał następująco: „A wiara jest gruntem rzeczy tych, których się spodziewamy, wywodem rzeczy niewidzianych". Rzecz ciekawa, że również staropolskie przekłady protestanckie nie poszły za przykładem Lutra. Biblia Brzeska (1563): „A wiarać jest

${ }^{5}$ Es ist aber der Glaube eine gewisse Zuversicht des, das man hofft, und ein Nichtzweifeln an dem, das man nicht sieht. 
grunt rzeczy, których się nadziewamy i okazanie niewidomych". Podobnie Biblia Gdańska (1632): „A wiara jest gruntem tych rzeczy, których się spodziewamy i dowodem rzeczy niewidzialnych".

Niestety, w drugiej połowie XX wieku również polskie przekłady katolickie oddają ten werset po lutersku. Biblia Tyniecka (1965): „Wiara zaś jest poręką tych dóbr, których się spodziewamy, świadectwem tych rzeczywistości, których nie widzimy”. Biblia Poznańska (1974): „Wiara jest mocnym przekonaniem, że istnieje to, czego się spodziewamy, jest świadectwem o wydarzeniach, których nie widzimy". Bp Kazimierz Romaniuk (1997): „Wierzyć zaś - to znaczy być pewnym, że się otrzyma to, czego się oczekuje; to znaczy być przekonanym o rzeczywistym istnieniu tego, czego się nie widzi".

W swojej encyklice Benedykt XVI z satysfakcją odnotowuje, że współczesna egzegeza protestancka dystansuje się od luterskiego rozumienia wiary. Papież cytuje wybitnego biblistę protestanckiego, Helmuta Köstera: „Obecnie nie można mieć wątpliwości, że ta protestancka interpretacja, która stała się klasyczną, jest nie do utrzymania" (Spe salvi, 7).

Zobaczenie w wierze wymiaru obiektywnego, odejście od jednostronnego sprowadzania wiary tylko do przekonań albo tylko do subiektywnej postawy ufności i zawierzenia, umożliwia rozpoznanie wiary jako początku życia wiecznego. „Wiara - cytuję teraz encyklikę Spe salvi, 7 - nie jest tylko skłanianiem się osoby ku rzeczom, jakie mają nadejść, ale wciąż są całkowicie nieobecne. Ona coś nam daje. Już teraz daje nam coś z samej oczekiwanej rzeczywistości, a obecna rzeczywistość stanowi dla nas «dowód» rzeczy, których jeszcze nie widzimy. Włącza przyszłość w obecny czas do tego stopnia, że nie jest ona już czystym «jeszcze nie». Fakt, że ta przyszłość istnieje, zmienia teraźniejszość; teraźniejszość styka się z przyszłą rzeczywistością, i tak rzeczy przyszłe wpływają na obecne i obecne na przyszłe".

Tę prawdę, że w wierze zaczyna się już życie wieczne, Tomasz z Akwinu podkreślał tak często $^{6}$, że przedstawienie tego tematu wymagałoby odrębnego wykładu. Tutaj ograniczę się do przytoczenia refleksji, jaką umieścił on we wstępie swojego Wykładu Składu Apostolskiego: „Dzięki wierze rozpoczyna się $w$ nas życie wieczne. Nie jest ono niczym innym, jak poznaniem Boga. To jest życie wieczne - mówi Jezus - aby znali Ciebie, jedynego prawdziwego Boga (J 17,3). Ta znajomość rozpoczyna się przez

${ }^{6}$ Por. np. Summa Theologiae, 1-2, q. 65, a. 5; 2-2, q. 4, a. 1; q. 5, a. 1; q. 19, a. 8; Quaestiones disputatae de veritate, q. 14, a. 2; Super Epistolam ad Hebreos, cap. 11 lect. 1, etc. 
wiarę, a osiągnie pełnię w życiu przyszłym, kiedy to będziemy oglądali Boga takim, jakim jest. Stąd czytamy w Liście do Hebrajczyków (11,1): Wiara jest podstawa tych dóbr, których się spodziewamy. Nikt zatem nie dojdzie do szczęścia błogosławionych, polegającego na bezpośredniej wizji Boga, jeśli przedtem nie oglądał Go w świetle wiary, jak to czytamy u św. Jana: Błogosławieni, którzy nie widzieli, a uwierzyli (J 20,29)"'7.

Streszczenie. Począwszy od epoki oświecenia istnieje w naszej kulturze tendencja do utożsamiania wiary z religijnym światopoglądem. Ponadto, często można się spotkać z tezą, jakoby wiara polegała na posiadaniu religijnych przekonań. Autor dokonuje analizy językowej Hbr 1,11 w kontekście ekumenicznym na podstawie encykliki Benedykta XVI Spe Salvi oraz tłumacznia i analizy zarówno katolickiego, jak i protestanckiego.

Słowa kluczowe: wiara; dar; Tomasz z Akwinu.

Abstract. Faith as the beginning of life everlasting. From the Enlightement onwards there is a tendency to identify faith with religious outlook. Moreover, one may notice an assumption, that faith consists of one's religious beliefs. The author makes an analysis of the Heb 1:11 in the context of Catholic-Protestant studies on that text, as well as the Church's teaching as presented in St. Thomas Aquinas' works and the Encyclical Letter Spe salvi.

Key words: faith; gift; Thomas Aquinas.

7 Wykład Składu Apostolskiego, tłum. Kalikst Suszyło, w: Tomasz z Akwinu, Dzieła wybrane, Kęty 1999, s. 576. 